\title{
Morphological and Histochemical Analysis of the Antennal Gland of Macrobrachium Potiuna (Muller, 1880) (Crustácea, Decapoda, Palaemonidae)
}

\author{
Neci Moraes ${ }^{1}{ }^{*}$ and Rejane Cirra Scaff ${ }^{2}$ \\ ${ }^{1}$ Departamento de Ciências Morfológicas - CCB - Universidade Federal de Santa Catarina - Campus \\ Universitário - Trindade - Florianópolis - Santa Catarina - CEP- 88.040-900
}

\begin{abstract}
The objective of our study was to describe by histologic methods the structural organization of the antennal gland of M. potiuna as well as the location through histochemical methods of the neutral and sulfated polissacharides that exist in these regions. This study showed that the gland is composed of the a non-secretive tubular portion and a secretive portion which is formed by a cubic simple epithelium, sub-epithelium layer and cellular chains
\end{abstract}

Key words: antennal gland, Macrobrachium potiuna, morphology, histochemistry

\section{INTRODUCTION}

Fresh and salt water shrimp and of the palaemonidae family, found in Latin America, are objects of commercial exploitation, due to their size and abundance (Boschi, 1974).

Among the palaemonidae, the genus Macrobrachium shows a great breeding potential, with the exception of M. potiuna, because it is small in size and demands very special environmental conditions.

The excretion system of shrimp of the genus Macrobrachium consists of two complex organs, in cephalic position, known as antennal glands, whose excretion orifices are located at the bases of the second pair of antennae. The antennal glands have the function of eliminating excreted substances from the animal's organism and maintaining the body's osmotic equilibrium.

Since the osmotic pressure of the water is higher than that of the hemolymph, a great quantity of water penetrates the organism, through the branchiae. This excess of water that penetrated the animal's body and spread through the tissues, is to be eliminated by means of the excretion system through an ultrafiltration process that takes place in the antennal glands. The toxic nitrogenated substances, mainly the amonnium carbonates, produced by the animal's metabolic mechanisms, are eliminated by the antennal glands and partially by the branchiae. (Ling, 1962).

The purpose of this study is to broaden the morphological and histochemical information concerning the biology of this species.

\section{MATERIAL AND METHODS}

Experiments were performed with the species Macrobrachium potiuna, coming from "Poção", in the area of "Corrego Grande" , city of Florianópolis, Santa Catarina, with a total of 10 (ten) samples. After removal, the antennal glands were placed in the Bouin mixture for 24 hours, dehydrated in an increasing series of ethylic alcohol and clarified in xylene. The fragments were immediately infiltrated and included in paraffin. 
For morphological studies, $5 \mu \mathrm{m}$ sections were colored by methods of hematoxilineeosine(Camargo, 1979), Gomori trichrome (Behmer et al., 1976) methods and light green-orange-G fucsine acid (V.O.F.).

For identification of polysaccharides and protein, through histochemical techniques, we utilized the methods of blue from toluidine (Gordon et al., 1973), alcian blue and yellow (Ravetto, 1964), Schiff periodic acid (PAS) (Hooghwinkel et al, 1975) and ninhydrinaSchiff (Yashuma et al, 1953).

For analysis and photography, we utilized the Olympus $\mathrm{BH} 2$ microscope equipped with an OIympus C-35-AD camera.

\section{RESULTS AND DISCUSSION}

The antennal glands of $M$. poriuna are made up of a secreting and a non-secreting portion (figs. 1, $2 \& 3$ ). The non-secreting portion consists of tubular structures that show a simple cubic epithelium with a spherical nucleus located in a central position, a very conspicuous nucleolus, colored reddish by Gomori trichrome and V.O.F., and orthochromatic blue from toluidine (figs. 6, 7, 8, 9. 10).

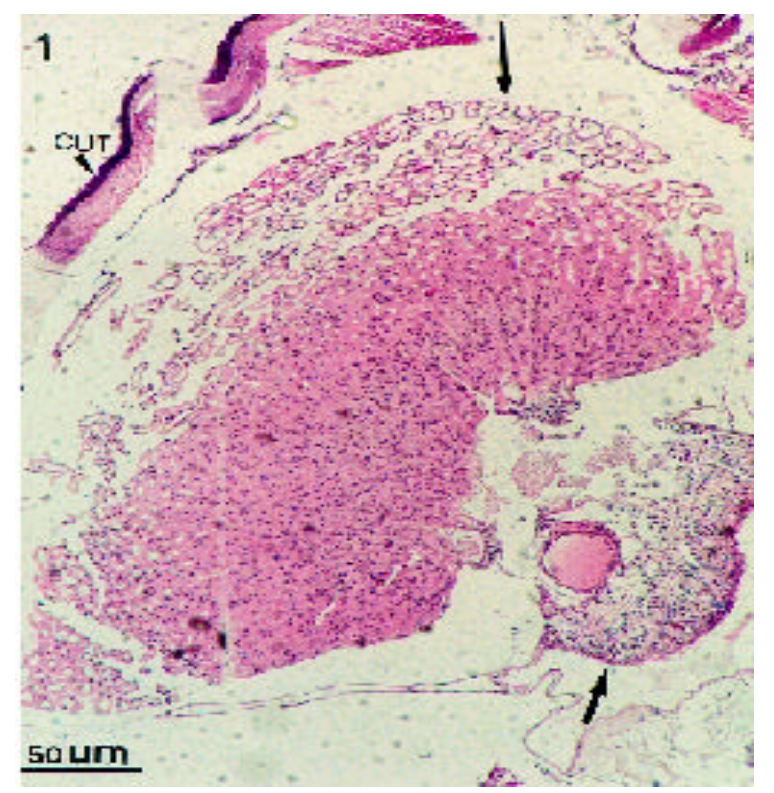

Fig. 1 - Longitudinal cut of the Antennal Gland. Overall view of secreting portion (thick arrow), non-secreting section (thin arrow) Cuticle (CUT). H.E.

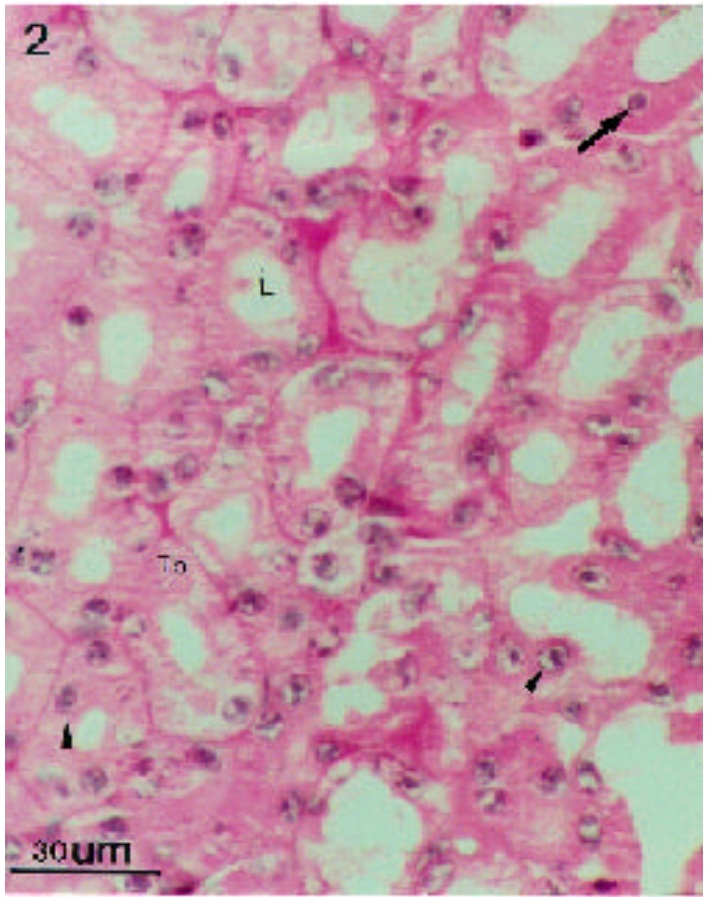

Fig. 2 - Non-secreting portion, with tubular structures (TB), lumen (L), nucleus (arrow point), nucleolus (thick arrow) H.E.

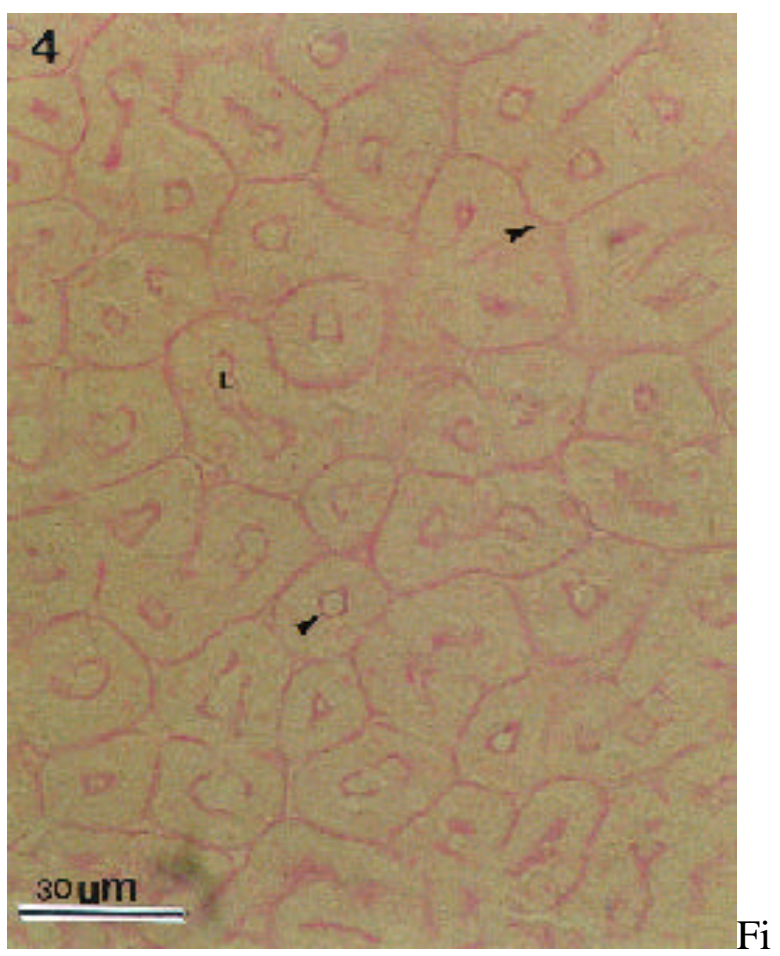

g.4 - Non-secreting portion. Tubular edges, positive reaction to neutral polysaccharides (arrow point), lumen (L). P.A.S. 


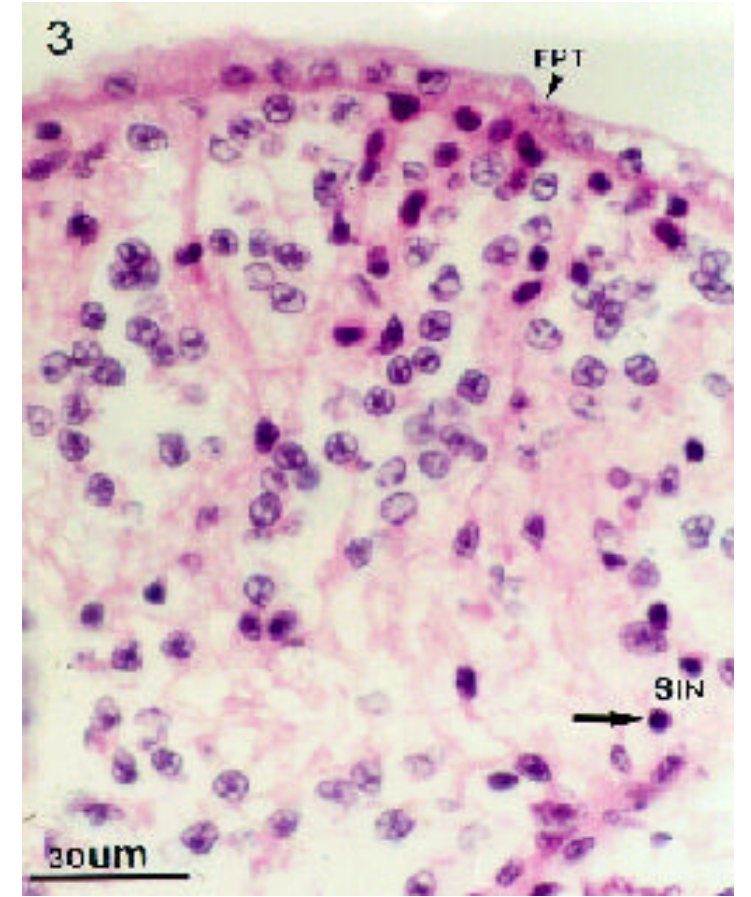

Fig.3 - Secreting portion, Simple cubic epithelium, hemolymphatic sinusoids (SIN), hemocrites (thick arrow). H.E.

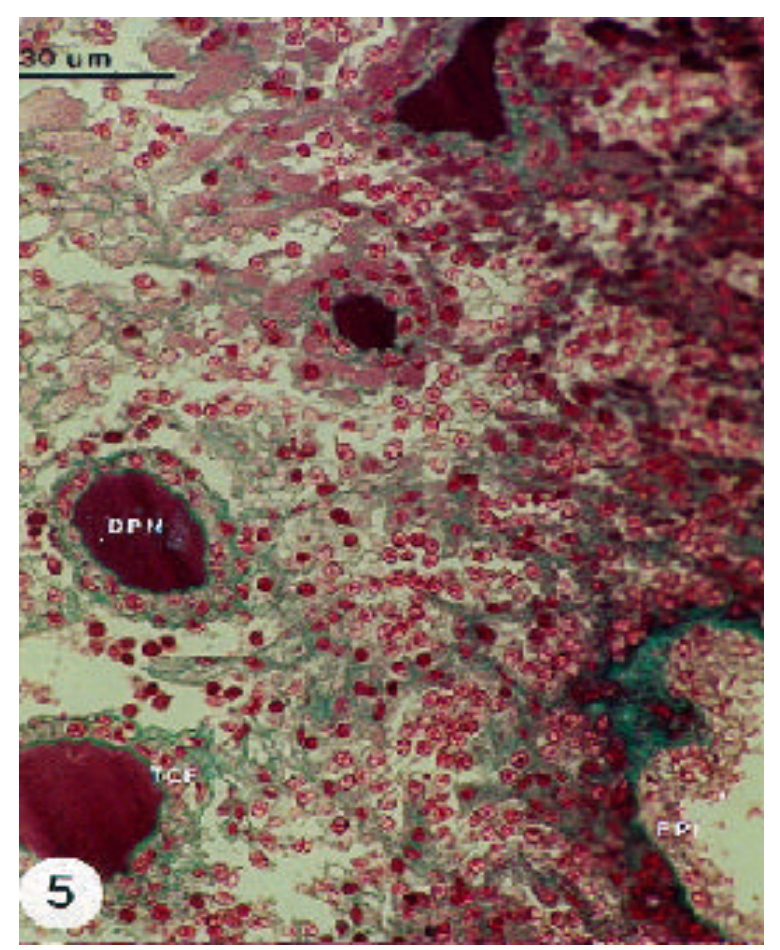

Fig.5 - Secreting portion. Simple, cubic epithelium (EPT), deposit of material (DPM). Fiber joining tissue(FJT), Gomori.

The tubules are covered externally by a thin layer of fiber joining tissue, colored green by Gomori trichrome and brown by V.O.F. (figs.5, 6, 7, 8), coinciding with the results observed by (Bell et al, 1988), in their studies of penaieds.

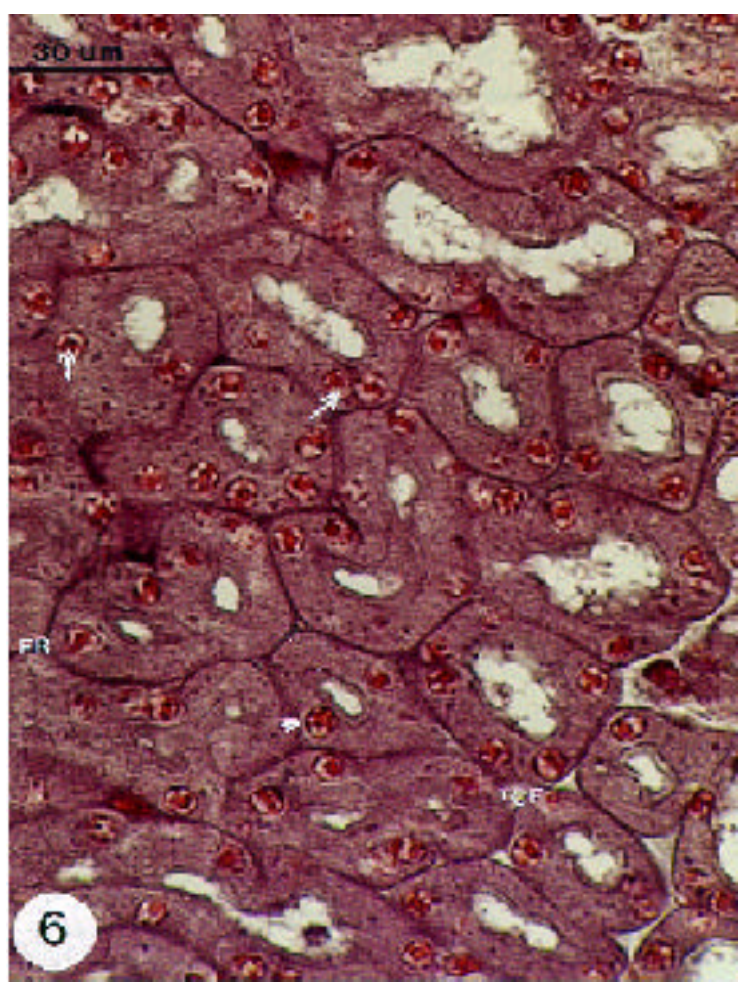

Fig.6 - Non-secreting portion. Among the tubules and hemolimphatic sinusoids, a layer of fiber joining tissue(FJT) and a colagen extract with a large quantity of reticular fibers(RF). Nucleus (arrow point), nucleolus (thick arrow) V. O. F.

Among the tubules, hemolymphatic sinusoids were found (Fig. 10). The total proteins were colored by the ninhydrina-Schiff test. These cellular types reacted slightly to the cytoplasmatic content and strongly to the nuclear content. (Fig. 10). The tubular edges reacted positively to the P.A.S. (Fig. 4). A similar reaction was observed with alcian blue.

The secreting portion is composed of a simple cubic epithelium that surrounds it externally (Fig. 3 ) and an non-cellular sub-epithelial layer, colored purple by eosine (which is an acid dye) revealing an acidophile, which, according to (Vidal et al, 1987) indicates the presence of a positively charged substrate amino groups of protein residue $\left(-\mathrm{NH}^{+}\right)$linking with negativelycharged acid dyes. 
Cellular cords interspersed with thin septa of joining tissue have been noted near the inner part of the secreting portion with the presence of a rich network of capillary sinusoids identified by means of hemocytes (SIN). These cellular cords are composed of cubic cells with a spherical and chromatin nucleus, forming filaments and a colored nucleoplasm, in which the nucleoli can be observed.

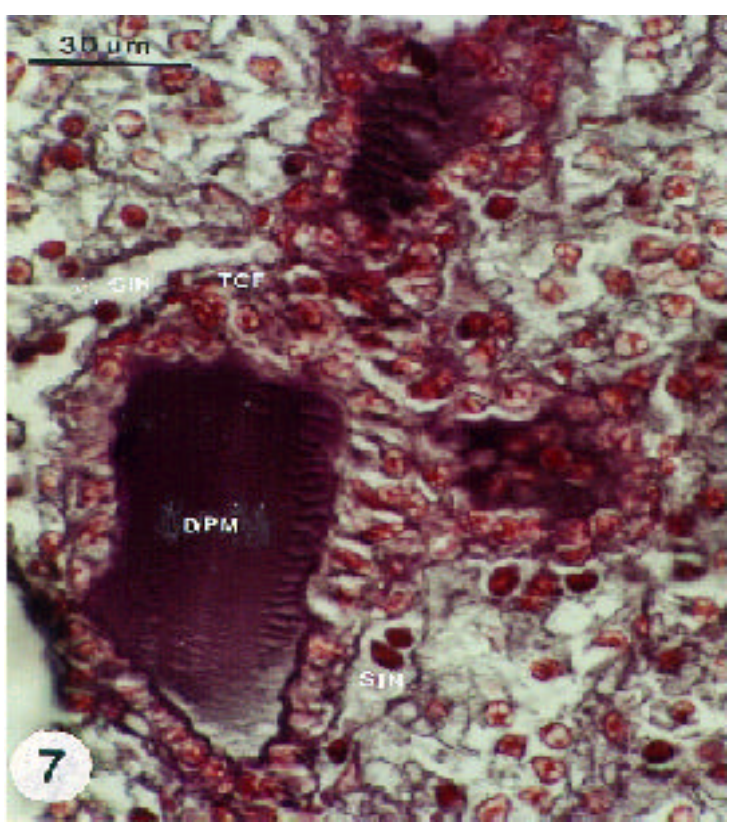

Fig. 7 - Secreting portion. Tubules with deposit of material(DPM). Fibrous joining tissue (FJT), hemolimphatic sinusoids (SIN). V. O. F.

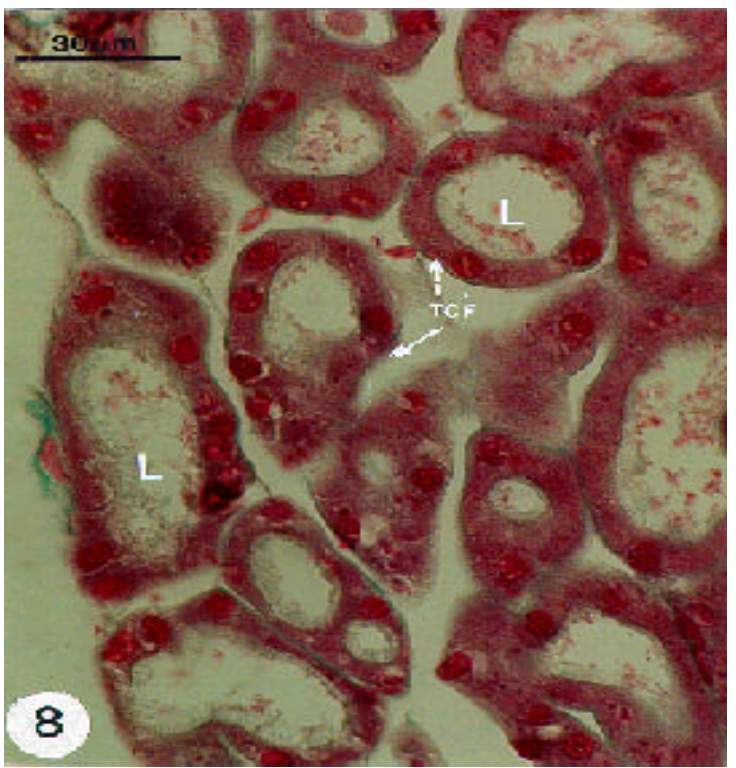

Fig. 8 - Non-secreting portion. Lumen (L), layer of fibrous joining tissue among sinusoids (FJT). GOMORI

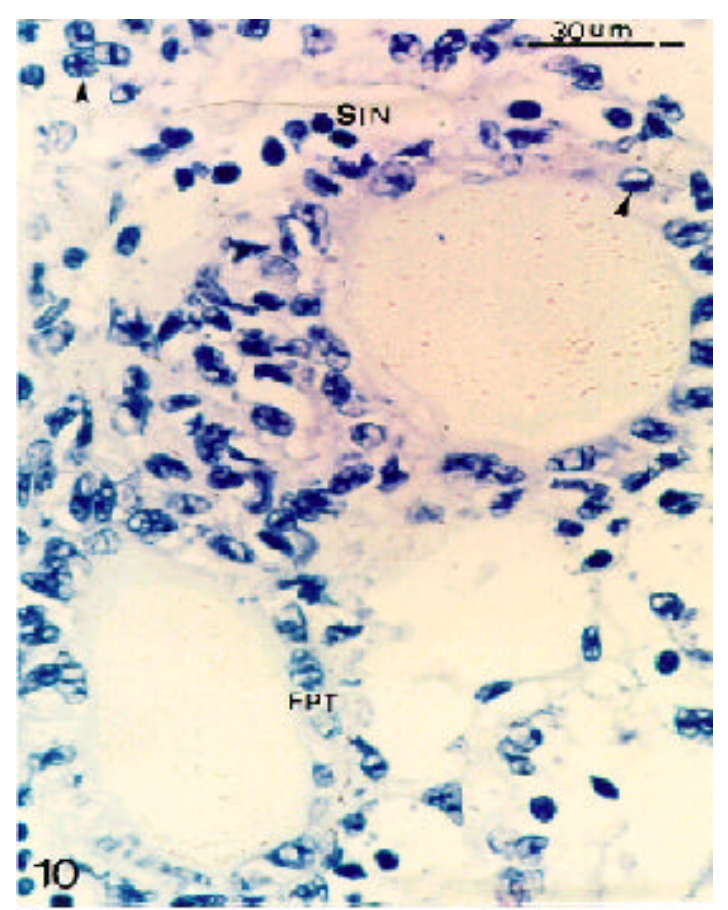

Fig;10 - Secreting portion. Simple cubic epithelium (EPI). Nucleus (arrow point), sinusoids with hemocites (SIN). Blue from toluidine.

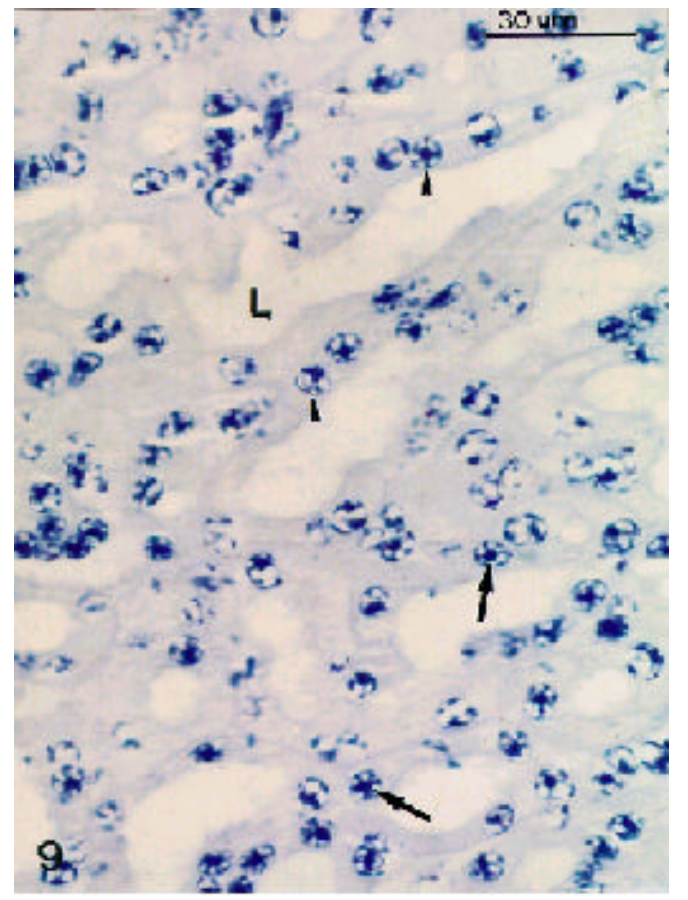

Fig.9 - Non-secreting portion. Nucleus (arrow point), nucleolus (thick arrow), lumen (L). Blue from toluidine. 


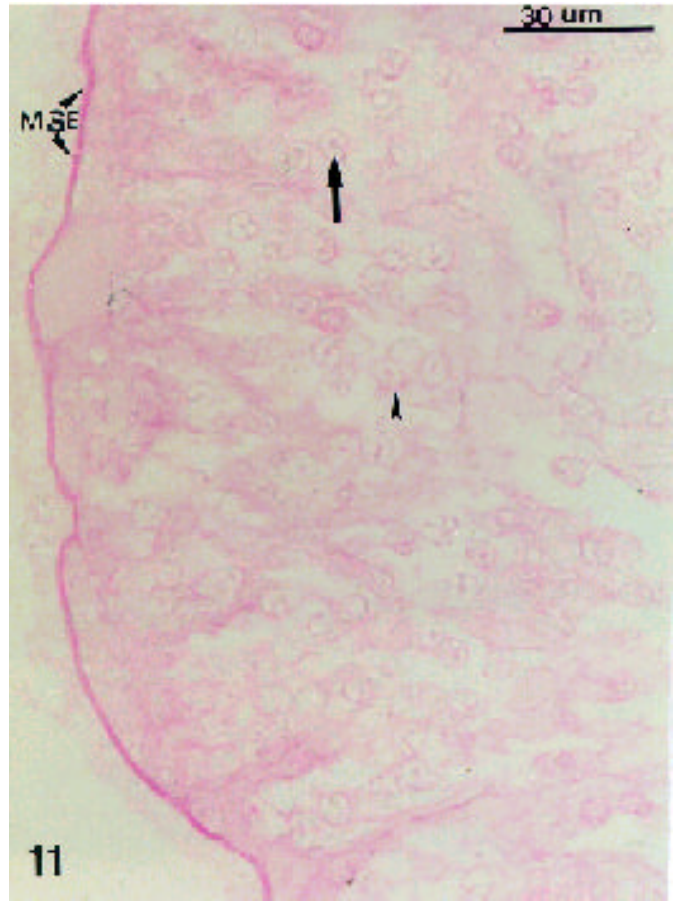

Fig. 11 - Secreting portion. Nucleus (arrow point), nucleolus (thick arrow), sub-epithelial layer (MSE). Ninhydrina - Schiff.

In these deep areas (figs. $5 \& 7$ ), the presence of follicles structures is also identified. These structures are clearly defined, consisting of a simple cubic epithelium, containing, in the lumen, a deposit of material, probably glycoproteins that are to participate in forming hormones that could influence the ecdyses or the maturation of the gonads of that species. These follicles are similar to the thyroidal follicles in mammals.

In fig. 11 the sub-epithelial layer is clearly in evidence due to a strongly violet coloration, revealing the presence of total proteins, demonstrated by the ninhydrina-Schiff method, which, according to (Yasuma et al, 1953), recognizes the lysin-type aminoacids, identifying the $\alpha \mathrm{NH}_{2}$ groups of amino-acid.

Through the oxidation of 1.2 glucol groups abundant in neutral polysaccharides (Gordon et al, 1973) by periodic acid, the gradual release of aldehyde, carbon dioxide $\left(\mathrm{CO}_{2}\right)$, and $\mathrm{NH} 3$, representing an amino-ionized group, occurs in several different stages.
The aldehyde radical linked to the protein reacts to the Schiff reactive, showing thereby a positive reaction to total proteins with the identification of the aminoacid, lysin, characterized by a violaceous coloring. This same reaction was also positive for the extracellular matrix and slightly positive for the edges of the nucleus. Complementary immunocytochemical studies are required to identify this content.

The reaction of alcian blue was shown to be slightly positive for the sub-ethelial layer and weak for the extracellular matrix, as well as for the cellular edges (fig. 12), indicating a low concentration of polysaccharide sulfates in these regions.

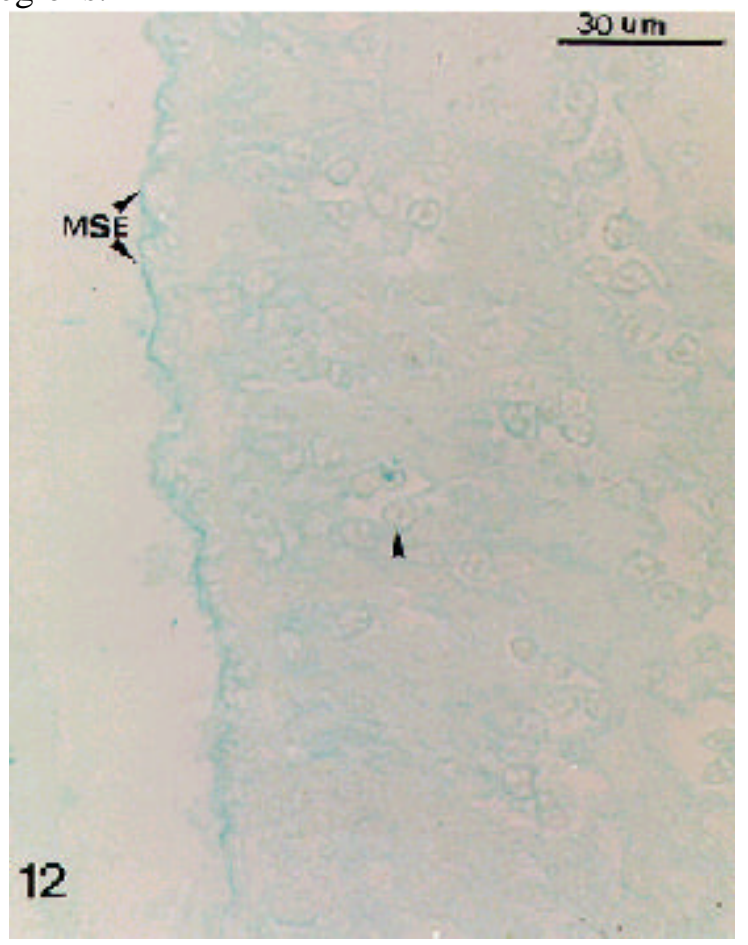

Fig. 12 - Secreting portion. Nucleus (arrow point),subepithelial layer (MSE). Alcian blue.

Investigating the properties of the alcian blue coloring, (Ravetto, 1964) and (Vidal et al, 1987) affirm that in $\mathrm{pH} 0.5$ the sulfated groups are identified, inasmuch as the carbolixic groups do not dissociate below $\mathrm{pH} 1.0$ according to the results obtained in our experiments.

For the identification of neutral polysaccharides, we utilized the P.A.S. reaction which was also slightly positive in this region. 


\section{REFERENCES}

Behmer, A. O., Talosa, C. M. E., Neto, F. G. A. (1976), Manual De Técnicas Para Histologia Normal e Patológica. EDART. Editora da Universidade de São Paulo. SP.

Bell, A. T., Leghtner, V. D. (1988), A Handbook of Normal Penaeid Schrimp. Histology. World Aquaculture Society Baton Rouge, Louisiana, pp. 108.

Boschi, E. E. (1974), Biologia de los crustaceos cultivables en America Latina. Carpas. 6: 1-24.

Camargo, M. L. Z. (1979), Guia de Técnicas Citológicas e Histoquímicas. Curitiba, 21f. (apostila mimiografada).

Gordon, E. M., Mccandless, E. L. (1973), Ultrastructure and hystochemistry of Chondrees crispus Stack. Proc. Nora Scot. Inst. sci., 27, 111-133. Supplement.
Hooghwinkel, G. I. M. And Smits, G. (1975), The Specificity Of The Periodic AcidSchiff tecnique studied by a quantitative test the method. I. Histochem. Citochem., 5: $120-126$.

Ling, S. W. (1962), Studies On The Rearing Of Larvae And Juvenile And Culturing Of Adults Of Macrobrachium rosenbergii (De Man). Tech. Pap. BPFC, 57: 15p. Apud Ling, S. W. \& Costello, T. J. 1976.

Ravetto, C. (1964), Alcian Blue - Alcian Yellow: A New Method For The Identification Os different acidic groups. I. Histochem. Citochem., 12: 44-45.

Vidal, B. C., Mello, M. L. S. (1987), Biologia Celular. Livraria Atheneu. Rio De Janeiro. São Paulo. pp. 25-29.

Yasuma, A., Ichikawa, T. (1953), Ninhydrina-Schiff An Alloxan-Schiff Staining. A New staining method for protein. I. Lab. Clin. Med., Stilous, 41: 296-29. 